\title{
Characterization of diversity and genetic structure in natural populations of Stryphnodendron adstringens (Mart.) Coville by means of allozyme markers
}

\author{
GLASENAPP, J.S. ${ }^{1 *}$; MARTINS, E.R. ${ }^{2}$; CASALI, V.W.D. ${ }^{3}$; CRUZ, C.D. ${ }^{1}$; BARBOSA, P.B. ${ }^{4}$ \\ ${ }^{1}$ Universidade Federal de Viçosa (UFV), Departamento de Biologia Geral, Av. PH Rolfs s $/$, Bairro Centro, Viçosa, \\ MG, CEP: 36570-000, *siqueiragaia@yahoo.com.br. ${ }^{2}$ Universidade Federal de Minas Gerais (UFMG), Instituto \\ de Ciências Agrárias (ICA), Campus Regional de Montes Claros, Av. Universitária, 1.000, Bairro Universitário, \\ Montes Claros, MG, CEP: 39404-547. ${ }^{3}$ Universidade Federal de Viçosa (UFV), Departamento de Fitotecnia, Av. \\ PH Rolfs s/n, Bairro Centro, Viçosa, MG, CEP: 36570-000. ${ }^{4}$ Universidade Federal de Lavras, Departamento de \\ Zootecnia, Caixa Postal 3037, Lavras, MG, CEP: 37200-000.
}

RESUMO: O S. adstringens, árvore típica do Cerrado, tem sido explorada visando suas propriedades medicinais e tanantes. Em razão do ainda incipiente conhecimento genético da espécie, este trabalho teve como objetivo caracterizar a diversidade e a estrutura genética de S. adstringens por meio de marcadores aloenzimáticos. Foram coletadas sementes em cinco mesorregiões brasileiras, sendo amostrados 627 indivíduos divididos em 16 populações localizadas nos Estados de Minas Gerais e Goiás. Foram testados 14 sistemas isoenzimáticos; destes, sete foram polimórficos com o total de 10 locos e 28 alelos. O valor de diversidade genética média $(H)$ foi 0,226 , a proporção média de locos polimórficos $(P)$ foi 68,75 , o número médio de alelos por loco polimórfico $(A P)$ foi 2,65 e o número efetivo de alelos $\left(A_{e}\right)$ foi igual a 1,29. Resultados do índice de fixação total $(F=0,003)$, do índice de fixação dentro de populações ( $f=$ $-0,114)$ e, da medida de diferenciação genética $(\theta=0,105)$ foram não significativos, indicando a inexistência de estruturação genética. Na análise de agrupamento (UPGMA) foram observados dois grupos principais, o primeiro formado pela população do Parque Estadual (PE) do Rio Preto (MG), e outro, formado pelas demais populações. Se excluída a população do PE do Rio Preto das análises, $G_{S T}$ é drasticamente reduzido de 0,077 para 0,026. Assim, aproximadamente $2 / 3$ do valor total de $G_{S T}$ verificado em $S$. adstringens foi devido à variação entre a população do $\mathrm{PE}$ do Rio Preto e as demais populações. De modo geral, os valores $\mathrm{H}$ e $\mathrm{P}$ observados em $\mathrm{S}$. adstringens são compatíveis aos constatados em árvores tropicais comumente distribuídas. Por outro lado, excluindo a população do PE do Rio Preto, o valor da medida de diferenciação genética $G_{S T}$ foi menor que o verificado em árvores tropicais nativas e pinheiros de zonas temperadas. A semelhança entre populações avaliadas indica que o fluxo gênico ainda é alto o suficiente para prevenir a diferenciação genética, pelo menos em nível local.

Palavras-chave: locos aloenzimáticos, diversidade genética, barbatimão, plantas medicinais.

ABSTRACT: Characterization of the diversity and genetic structure in natural populations of Stryphnodendron adstringens (Mart.) Coville by means of allozyme markers. The S. adstringens, a typical Cerrado (Brazilian savannah) tree, is used because of its medicinal and tanning properties. Because of the still incipient genetic knowledge of the species, the objective of this work was to characterize the diversity and genetic structure of $S$. adstringens by using allozyme markers. Seeds were collected in five Brazilian mesoregions, in which 627 individuals in 16 populations in the states of Minas Gerais and Goiás were sampled. Fourteen isoenzyme systems were assessed, out of which seven were polymorphic with a total of 10 loci and 28 alleles. Average genetic diversity $(H)$ was 0.226 , average proportion of polymorphic loci $(P)$ was 68.75 , average number of alleles per polymorphic locus $(A P)$ was 2.65 and effective number of alleles $\left(A_{e}\right)$ was equal to 1.29. The results of total fixation index $(F=0.003)$, within population fixation index $(f=-0.114)$ and genetic differentiation measure $(\theta=0.105)$ were not significant, which shows the inexistence of genetic structure. Two principal groups were found in the cluster analysis (UPGMA), where the first one was formed by the population of State Park (PE) of Rio Preto (MG) and the other, by the other populations. If the population of PE of

Recebido para publicação em 21/08/2012

Rev. Bras. PI. Med., Campinas, v.16, n.2, p.216-224, 2014. 
Rio Preto is excluded from the analysis, $G_{S T}$ is drastically reduced from 0.077 to 0.026 . Thus, approximately $2 / 3$ of the total value of $G_{S T}$ found in $S$. adstringens was due to the variation among the population of PE of Rio Preto and the other populations. Overall, the values of $H$ and $P$ found in $S$. adstringens are compatible with the ones found in typically distributed tropical trees. On the other hand, by excluding the population of PE of Rio Preto, the value of the $G_{S T}$ genetic differentiation measure was smaller than the one found in native tropical trees from temperate zones. The similarity between the assessed populations shows that the gene flow is still high enough to avoid genetic differentiation, at the local level, at least.

Keywords: allozyme loci, genetic diversity, "barbatimão”, medicinal plants.

\section{INTRODUCTION}

Stryphnodendron adstringens (Mart.) Coville, popularly known as barbatimão, is a small tree, typically occurring in Cerrado-field and in stricto sensu cerrado, in primary and secondary formation. Its distribution covers the states of Pará, Tocantins, Bahia, Distrito Federal, Goiás, Mato Grosso, Mato Grosso of Sul, Minas Gerais, São Paulo and northern Paraná (Felfili \& Borges Filho, 2004; Almeida et al., 1998).

Because of its medicinal properties, it is used in the treatment of diseases such as ulcers, inflammation and hemorrhoids (Barros, 1982). Its stem bark is antiseptic and used for gastritis, sore throat (Hirschmann \& Arias, 1990), scurvy wounds, leucorrhea, hernia, diarrhea, hemorrhage, impinge and ophtalmias (Almeida et al., 1998). In 2009, the Agência Nacional de Vigilância Sanitária - Anvisa (Brazilian Sanitary Surveillance Agency) granted the first registration for a medicine elaborated from a plant from the Cerrado. The ointment FITOSCAR consists of dry extract $S$. adstringens, which has healing effects

Nowadays, the traditional use of bark extraction with commercial purposes, associated to the cutting down of trees have been putting this species in a situation of extinction threat (Souza \& Felfili, 2006).

The need for elaborating politics towards the development of techniques of management and domestication of $S$. adstringens is highlighted by some researchers (Assunção \& Felfili, 2004; Felfili \& Borges Filho, 2004; Jacobson et al., 2005).

The understanding of genetic variation is a crucial pre-requisite for decision taking regarding to strategy of preservation and management of native tropical trees. However, only a small part of genetic diversity of tropical trees has been investigated so far in an extensive manner (Whitmore, 1980; Hamrick, 1983; Bawa \& Ashton, 1991).

As the population structure of a species is made up of a varied number of local populations. The genetic structure should be characterized not only in terms of each population but also in relation to the differences among populations. Local population which can become structurally and genetically distinct by genetic drift, mutation or divergent selection also may have their differences reduced by migration and uniform selection.

Among the markers used in the analysis of genetic structure of the species, allozymes stand out providing a method to evaluate genetic variation in population of tropical trees and to measure population process of ecological, preservationist and forestry management importance (Loveless, 1992). The utilization of allozyme techniques can largely increase the understanding on the genetic structure of tropical species. Eletrophoretic data may be achieved from any species with no previous knowledge of the genome (Alfenas et al., 2006), thus, they are the very ideal ones for characterization of genetic structure of natural population of tropical plants. Therefore, because of the need in setting policies towards management and preservation, and because of the incipient knowledge of its population genetic structure, the objective of this work was to characterize genetic variation in $S$. adstringens by using allozyme markers.

\section{MATERIAL AND METHODS}

Collection was performed from September to November in 2009, in five mesoregions delimited according to the Brazilian Institute of Geography and Statistics (IBGE). It was sampled 627 individuals divided into 16 populations, 15 populations in Minas Gerais State and one in Goiás State. Because S. adstringens has its pod predated by many species of insects, by precaution against failed seed germination, were sampled five ripen fruit per plant, but only a seed of each plant was considered for the electrophoresis. The transects were carried out in the woods, on foot or by car whenever possible, respecting a minimum space of 60 meters in a straight line between sampled plants. Fruits were packaged in paper bags, properly labeled and kept like that until arrival at Vegetable Breeding Laboratory of the Federal University of Viçosa. Wood conditions were observed during collection and over 
walks on the roads.

In the mesoregion of Jequitinhonha, populations of Parque Estadual (PE) of Biribiri, of PE of Rio Preto and Parque Nacional (PN) of Sempre Vivas were sampled in the region of Diamantina. This region has shallow sandy, rocky and acid soils and a mild weather. Vegetation is well preserved, probably because the soils are not propitious for farming (IBGE, 1997). In the mesoregion of Capelinha, populations of Tourmaline, Carbonite and Poço D'anta were sampled. This mesoregion is extremely deforested and had extension plantation of eucalyptus. Except for Poço D'anta, a private estate with well preserved vegetation, collections were carried out in paths of reminiscent wood on the borders of the roads in areas that belong to DNIT - Departamento Nacional de Infra-Estrutura de Transportes (Brazilian Department of Transportation Infrastructure) or to DER/MG - Departamento de Estradas de Rodagem de Minas Gerais (Road Department of the State of Minas Gerais).

Populations of Pirapora, Brasília de Minas, Serra Nova and Montes Claros were sampled in the Norte de Minas mesoregion. By excluding the population of Serra Nova, where extensive areas with native vegetation can still be seen, collections were basically carried out very close to the roads. Because of deforestation, collection in the region of Brasília de Minas was done in the area of natural vegetation belonging to runway of the city airport. Extensive deforested region were found in this local, and according to information of the local native people, there used to be large populations of Barbatimão in this region. Norte Mineira mesoregion presents very similar physical characteristics to the Northeastern region in Brazil. The climate is semiarid with high temperatures, rainfall concentrated in few months in the year, among long periods of drought.

In the mesoregion of Distrito Federal, collections were carried out in Fazenda Água Limpa (FAL), which belongs to Universidade de Brasília (UnB), inserted in the Environmental Protection Area (Area de Proteção Ambiental - APA) of Gama and Cabeça do Veado Basins. Typical vegetation of Cerrado was not found between Patos de Minas and Distrito Federal (BR 040), only in few locals, most of the time in areas which belong to DNIT on the board of the highway, when they were not cutdown by farmers and used for farming.

In Alto Parnaíba, microregion of Patos de Minas, the population of Patos de Minas was sampled. The typical vegetation is "cerradão" and it is also found confined to areas occupied by highways. The climate is characterized as tropical with hot and wet summers and dry winter with mild temperatures (Mello, 2008).
In the central mesoregion, it was sampled the population of São Gonçalo of Rio das Pedras, which belongs to Conceição do Mato Dentro, located in the central region of Serra do Espinhaço. São Gonçalo of Rio das Pedras has well preserved vegetation, typical of high Cerrado (IBGE, 2008).

The number of plants sampled in each population was 40 at São Gonçalo das Pedras, 41 at Carbonita, 34 at Serra Nova, 22 at Patos de Minas, 62 at FAL, 34 at P.N. of Sempre Vivas, 33 at Brasília de Minas, 37 at Riacho da Porta, 31 at Araçuaí, 42 at Coração de Jesus, 32 at Turmalina, 37 at P. E. of Biribiri, 42 at Pirapora, 44 at Montes Claros, 33 at Poço D'anta, 53 at P.E. of Rio Preto. Three seeds of each sampled plant were germinated in growth chamber, but only one seedling of each sampled plant was subjected to starch-gel electrophoresis. The proportion of $1 \mathrm{~g}$ of the macerated of each seedling was added into every $3 \mathrm{~mL}$ of extraction solution number 1 recommended by Alfenas et al. (2006). The gels were prepared with $3 \%$ of saccharose and $12 \%$ of corn starch per $100 \mathrm{ml}$ of gel buffer solution. Buffer systems suggested by Soltis et al. (1983) and by Shaw \& Prasad (1970), described in Table 1, were used in the experiment. Pre-race was conducted 15 minutes away for 30 minutes and using the buffer system I and for 1 hour, using the buffer system II. Race was performed 35 mA away for about 5 hours. Isoenzyme systems analyzed by the buffer system I were the following: esterase (EC 3.1.1.1, EST), acid phosphatase (EC 3.1.3.2, ACP), phosphoglucomutase (EC 5.4.2.2, PGM), phosphoglucose isomerase (EC 5.3.1.9, PGI), glycerate-2-dehydrogenase (EC 1.1.1.29, G2D) glucose dehydrogenase (EC 1.1.1.47, GDH) glucose-6-phosphate dehydrogenase, (EC 1.1.1.49, G6PDH) glutamate oxaloacetate transaminase (EC 2.6.1.1, GOT), leucine aminopeptidase (EC 3.4.11.1, LAP) and peroxidase (EC 1.11.1.7, PER). The isoenzym systems analyzed with the buffer system II were the following: alcohol dehydrogenase (EC 1.1.1.1, $\mathrm{ADH}$ ), isocitrate dehydrogenase (EC 1.1.1.42, IDH), malate dehydrogenase (EC 1.1.1.37, $\mathrm{MDH})$ and shikimate dehydrogenase (EC 1.1.1.25, SKDH).

Allozyme loci were identified by using the same abbreviations used in the denomination of each enzyme (for example, MDH), but with italic and lower case letters, followed by increasing numeric order form the slowest migration locus (for example, $m d h-1)$. The alleles in each locus were alphabetically ordered, with the fastest migration allele identified by $a$, and the slower migration alleles following that order.

According to the recommendations of Berg \& Hamrick (1997), the loci showing variation in at least one individual were considered polyphormic. 
TABLE 1. Composition of buffer solutions used in electrophoreses of seedling from sampled populations of $S$. adstringens.

\begin{tabular}{|c|c|c|}
\hline Buffer solution & Electrode & Gel \\
\hline 1 & 4.0 g.L $\mathrm{L}^{-1} \mathrm{NaOH}, 18.55 \mathrm{~g} \cdot \mathrm{L}^{-1}$ boric acid $(\mathrm{pH} 8.6)$ & $\begin{array}{l}40 \mathrm{~mL} . \mathrm{L}^{-1} \text { electrode solution, } 1.84 \mathrm{~g} . \mathrm{L}^{-1} \text { Tris, } \\
\left.0.69 \mathrm{~g} . \mathrm{L}^{-1} \text { citric acid ( } \mathrm{pH} 7.8\right)\end{array}$ \\
\hline II & Tris $16.35 \mathrm{~g} . \mathrm{L}^{-1}, 9.04 \mathrm{~g} . \mathrm{L}^{-1}$ citric acid $(\mathrm{pH} 7.0)$ & $66.7 \mathrm{~mL} . \mathrm{L}^{-1}$ electrode solution $(\mathrm{pH} 7.0)$ \\
\hline
\end{tabular}

I- Soltis et al. (1983), II- Shaw and Prasad (1970)

The proportion of poliphormic loci $(P)$, average number of alleles per polyphormic loci $(A P)$ and the effective number of alleles $\left(A_{e}\right)$ per locus were all measured. Deviations of allelic frequencies from EHW conditions were checked by means of Fisher's exact test. The expected heterozygosis estimate or genetic diversity $(H)$ was carried on.

Analysis of variance of allelic frequencies was carried out by partition of total variance of allelic frequencies in components related to hierarchical subdivisions of the genes. Thus, the non-target values $\left(\theta=F_{S T}, F=F_{I T}\right.$, and $\left.f=F_{I S}\right)$ were obtained from $F$ statistics over the loci, according to the models proposed by Weir \& Cockerham (1984). Alternatively to analysis of variance, the same parameters of genetic diversity $(\theta, F$, and $f)$ were achieved by means of "jackknifing" resampling alternative. Confidence intervals (IC) at the level of $95 \%$ were set by 1000 "bootstrapping" resamplings over the loci.

Population inbreeding coefficient $\left(f_{e}\right)$ was calculated by using the expression $f_{e}=1-$, where the expected heterozygosis is given by $H=1-\Sigma p_{i}^{2}$, and is the frequency of the $i^{\text {th }}$ allele in the population. The tests of significance for this parameters $\left(f_{\mathrm{e}}\right)$ were carried out by using the method proposed by Li \& Horvitz (1953). Those researchers reformulated the $X^{2}$ in terms of $\mathrm{F}$ statistics as $x^{2}=f_{e}^{2} N(a-1)$, with degrees of freedom $d f=\frac{a(a-1)}{2}$ where $\mathrm{N}$ is equal to the number of sampled individuals and $a$ is the number of alleles. Each locus was tested separately and the values of $X^{2}$ degrees of freedom were summed over all loci, therefore, achieving $x^{2}$ total value of the average coefficient $f_{e}$ in each coefficient. The effective population size $(\mathrm{Ne})$ was obtained by the means of the equation $\widehat{N} e=N /\left(1+\hat{f}_{e}\right)$, suggested by Vencovsky (1997) for a single population with lack of genetic structure, in which $N$ is the number of sampled individuals, and $\hat{f}_{e}$ ) is the coeficient of estimate population inbreeding. Cluster analysis was carried out by UPGMA technique by using matrix of genetic diversity $\left(\mathrm{G}_{\mathrm{ST}}\right)$ among populations. Average amount of gene flow, or the number of migrants per generation $(\mathrm{Nm})$, indirectly obtained among pairs of populations by the mathematical model of balance between gene flow and genetic drift, by using the method of Crow \& Aoki (1984), with $F_{S T}=1 /(4 \alpha N m+1)$ where $\alpha=[n /(n-1)]^{2}$ and $n$ is equal to the number of subpopulations.

Statistical analysis was carried out by using computer softwares in statistical and genetics GENES (Cruz, 2008) and Fstat (Goudet, 2002).

\section{RESULTS AND DISCUSSION}

Of the 14 assessed allozyme systems, it was observed 10 poliphormic loci and the total of 28 alleles (Table 2). Of the $160 \mathrm{EHW}$ tests (16 populations and 10 loci), obtained by Fisher's exact test, only 17 showed significant deviations $(P \leq 0.05)$ (not sampled data). The number of sampled individuals per population and estimates of genetic diversity $(H)$, proportion of poliphormic loci $(P)$, average number of alleles per polyphormic loci $(A P)$, inbreeding population coefficient $\left(f_{e}\right)$ and sample effective sizes $(\mathrm{Ne})$, are shown in Table 3. Proportion of polyphormic loci $(P)$ ranged from 60 to $80 \%$. The average number of alleles per polyphormic locus $(A P)$ was larger in the population of Brasília de Minas (3.00) and the smallest in Poço D'anta (2.37). Index of genetic diversity $(H)$ and the effective number of alleles $\left(A_{e}\right)$ ranged from 0.1820 to 1.22 in the population of Coração de Jesus and from 0.2698 to 1.40 in the PE of Rio Preto, respectively. The effective number of alleles $\left(A_{e}\right)$ measures both

TABLE 2. Loci and alleles observed in the results of electrophoretic analysis of sampled populations of $S$. adstringens.

\begin{tabular}{|c|c|c|c|c|c|c|c|c|c|c|}
\hline & \multicolumn{10}{|c|}{ Locus } \\
\hline & est-1 & est-2 & est-3 & est-4 & got-1 & pgi-1 & $m d h-4$ & $i d h-1$ & $a d h-1$ & skdh-1 \\
\hline $\begin{array}{c}\text { Number of } \\
\text { alleles }\end{array}$ & 2 & 2 & 3 & 3 & 3 & 2 & 3 & 5 & 2 & 3 \\
\hline
\end{tabular}


number of alleles and uniformity of allelic frequencies in one locus. More precisely, $A_{e}$ measures uniformity of the common alleles because rare alleles contribute little in the sum (Berg \& Hamrick, 1997).

By considering all populations, average genetic diversity $(H)$ was 0.226 , average proportion of polyphormic loci $(P)$ was $68.75 \%$, average number of alleles per polyphormic alleles $(A P)$ was 2.65 and the effective number of alleles $\left(A_{e}\right)$ was 1.29. Average values of $A_{e}$ are tipycaly found between 1.10 and 1.40 although higher values can be found in highly polyphormic species (Berg \& Hamrick, 1997). Branco et al. (2010), obtained estimates of the average number of alleles per polyphormic locus $(A P)$ between four and nine, and the proportion of polyphormic locus $(P)$ equal to $100 \%$ when studying five natural populations of $S$. adstringens by means of microsatellites markers.

Average value of genetic diversity $(H=0.226)$ was compatible to the one found in tropical trees with geographical distribution classified as regional and commonly distributed (Loveless \& Hamrick, 1984). Overall, species widely distributed have a higher genetic diversity proportion $(H)$ than geographically limited species (Hamrick et al., 1992).

Branco et al. (2010) found values of expected average heterozygosis $(H)$ equal to 0.7139 when using microsatellites markers. The discrepancy between values of expected average heterozygosis for microsatellite loci in relation to the one expected for allozymes may be explained by a larger number of alleles commonly found in microsatellite locos. The greater number of alleles in a locus, and greater value of expected heterozygosis, which reaches its peak when allelic frequencies are equivalent.

The representativeness of population samples of $S$. adstringens can be regarded as satisfactory since population effective sizes $(\mathrm{Ne})$ estimated in all populations were larger than the number of sampled individuals. Estimated $\mathrm{Ne}$ as proposed by Vencovsky (1997) measures representativeness of a sample of individuals or seeds. Results of estimates of the number of migrants per generation $(\mathrm{Nm})$ among population pairs (data not shown), showed that gene flow (>1) is sufficient for preventing differentiation of allelic frequencies by gene drift among all populations, except in PE of Rio Preto which presented all values of gene flow lower than one (0.1 a 0.16), showing reduced amount of migrants per generation. Estimates of population inbreeding coefficient $\left(f_{e}\right)$ did not significantly differ from balance expectations showing the existence of panmixia in most populations, except in PE of Biribiri and Montes Claros, where a significant excess of heterozygote was found (Table 3). An overdominance or selective advantage of the heterozygote has been being a frequent explanation for maintainance of genetic variation in natural populations (AlvarezBuylla et al., 1996). However, there is a considerable deficiency in the understanding of the process that leads to the excess of heterozygote (Gemmell \& Slate, 2006; Stoeckel et al., 2006), but as enzyme polyphormism is selectively neutral, or poorly linked to the adaptive value, selection of enzyme loci is relatively rare (Endler, 1986).

Results of ANOVA of allelic frequencies were compatible to the results obtained by numeric resampling technique. Confidence intervals $(\mathrm{Cl})$ at the level of $95 \%$, achieved by 1,000 bootstrapping resampling over the loci, show a genetic structure regarded to loci est-4 and pgi-1 in all evaluated parameters $(F, \theta, \mathrm{f})$, and the estimates obtained for loco pgi-1 are substantially higher than the others. Whereas the excess of heterozygote was evident in locus est-4, a lack of heterozygote was found in locus pgi-1 (Table 4). The results of genetic divergence among populations $(\theta)$ for loci $m d h-4$ and skh-1 were significant. A significant deficiency of heterozygote $(f)$ in populations was found for loci got-1, skh-1 and adh-1. Significant deviations for $F, \theta$ and $f$ were not found in the estimates obtained for total population.

Branco et al. (2010), found values of genetic divergence among populations of $S$. adstringens $(\theta=0.0145)$ lower than the one obtained in this study $(\theta=0.105)$. The non-agreement between $\theta$ measures in relation to the different markers is explained by the fact that microsatellite loci, because of being highly polymorphic, usually have small $\mathrm{G}_{\mathrm{ST}}$ (or $\theta$ ) values (Nei \& Kumar, 2000). Total and intrapopulation inbreeding coefficients obtained by allozymes ( $F$ $=0.003$ and $f=-0.114$ ) in the present study were considerably smaller than the ones obtained by microsatellites $(F=0.3623$ and $f=0.3529)$.

The value of genetic differentiation in $S$. adstringens $(\theta=0.105)$ was lower than the one found in trees native to Cerrado, as palm tree (Euterpe edulis) $(\theta=0.12)$ (Gaiotto et al., 2003), Anonna crassiflora $(\theta=0.127)$ (Telles et al., 2003a) and Eugenia dysenterica $(\theta=0.154)$ (Telles et al., 2003b). Overall, population of highly subdivided plants present high values of population genetic differentiation ( 0.20 or more), whereas large and continuous populations, as pine trees of temperate zones, tend to present diferentiation values of 0.05 or less (Loveless \& Hamrick, 1984; Hamrick \& Godt, 1989).

Thus, despite the reduction in the population sizes due to the deforestation, populations of $S$. adstringens keep high levels of genetic variability where some impact would be expected. Feyissa et al. (2007), in a study on Hagenia abyssinica, found that despite the recent anthropic disturbance, estimates of genetic diversity are typical and

Rev. Bras. PI. Med., Campinas, v.16, n.2, p.216-224, 2014. 
TABLE 3. Sample sizes, genetic diversity $(H)$, proportion of polymorphic locus $(P)$, average number of allele per polymorphic locus $(A P)$, population inbreeding coefficient $\left(f_{e}\right)$ and sample effective sizes $(\mathrm{Ne})$ estimated in sampled populations of $S$. adstringens.

\begin{tabular}{|c|c|c|c|c|c|c|c|}
\hline Population & & & $(\%)$ & & & $f_{e}$ & $\mathrm{Ne}$ \\
\hline S. G. Rio das Pedras & 40 & 0.2491 & 80 & 2.87 & 1.33 & -0.1575 & $46.7 \varepsilon$ \\
\hline Carbonita & 41 & 0.2100 & 60 & 2.83 & 1.26 & -0.1034 & 45.10 \\
\hline Serra Nova & 34 & 0.2306 & 60 & 2.67 & 1.30 & -0.1384 & 38.77 \\
\hline Patos de Minas & 22 & 0.2134 & 60 & 2.50 & 1.27 & -0.0644 & 22.89 \\
\hline FAL & 62 & 0.2656 & 80 & 2.62 & 1.36 & -0.1151 & 69.35 \\
\hline PN of Sempre Vivas & 34 & 0.2167 & 60 & 2.67 & 1.28 & -0.0313 & 35.35 \\
\hline Brasília de Minas & 33 & 0.2135 & 60 & 3.00 & 1.27 & -0.1414 & 37.17 \\
\hline Riacho da Porta & 37 & 0.2209 & 70 & 2.71 & 1.28 & -0.2416 & 47.95 \\
\hline Araçuaí & 31 & 0.2292 & 60 & 2.67 & 1.30 & -0.1433 & 35.47 \\
\hline Coração de Jesus & 42 & 0.1820 & 70 & 2.57 & 1.22 & -0.1449 & 48.44 \\
\hline Turmalina & 32 & 0.2262 & 80 & 2.50 & 1.29 & -0.0472 & 33.03 \\
\hline PE of Biribiri & 37 & 0.2554 & 80 & 2.62 & 1.34 & $-0.1492^{*}$ & 42.82 \\
\hline Pirapora & 42 & 0.1973 & 70 & 2.71 & 1.24 & -0.1776 & 50.36 \\
\hline Montes Claros & 44 & 0.1913 & 60 & 2.67 & 1.24 & $-0.2105^{*}$ & 54.93 \\
\hline Poço D'anta & 33 & 0.2398 & 80 & 2.37 & 1.30 & -0.1839 & 39.71 \\
\hline PE of Rio Preto & 63 & 0.2698 & 70 & 2.43 & 1.40 & -0.0275 & 64.22 \\
\hline Mean & 39.19 & 0.226 & 68.75 & 2.65 & 1.29 & - & - \\
\hline
\end{tabular}

$P E=$ Parque Estadual, PN=Parque Nacional, FAL=Fazenda Água Limpa - Universidade Federal de Brasília (UnB), S. G. Rio das Pedras = São Gonçalo of Rio das Pedras;

Significance tests $\left(X^{2}\right)$ for the coefficient $(f)$ as proposed by Li and Horvitz (1953), * Significant at the levels of $5 \%$ of probability.

TABLE 4. Results of estimates of total allelic fixation (F), allelic divergence among populations $\theta$ and fixation within population ( $f$ ), achieved by analysis of variance of allelic frequencies (ANOVA) (Weir \& Cockerham 1984) and "Jackknifing"resampling techniques.

\begin{tabular}{lllllll}
\hline \multirow{2}{*}{ Locos } & ANOVA & \multicolumn{5}{l}{ Jackknifing } \\
\cline { 2 - 7 } & $\mathrm{F}$ & $\theta$ & $F$ & $F$ & $\theta$ & $f$ \\
\hline est-1 & -0.012 & 0.048 & -0.063 & -0.015 & 0.069 & -0.087 \\
est-2 & 0.002 & 0.094 & -0.101 & 0.011 & 0.112 & -0.112 \\
est-3 & -0.06 & 0.046 & -0.111 & -0.058 & 0.048 & -0.111 \\
est-4 & $-0.208^{*}$ & $0.023^{*}$ & $-0.236^{*}$ & $-0.208^{*}$ & $0.023^{*}$ & $-0.237^{*}$ \\
got-1 & 0.197 & 0.034 & $0.169^{*}$ & 0.203 & 0.035 & $0.174^{*}$ \\
pgi-1 & $0.631^{*}$ & $0.625^{*}$ & $0.017^{*}$ & $1.008^{*}$ & $1.006^{*}$ & $0.013^{*}$ \\
mdh-4 & -0.008 & $0.030^{*}$ & -0.039 & -0.009 & $0.029^{*}$ & -0.040 \\
idh-1 & 0.027 & 0.1 & -0.082 & 0.037 & 0.108 & -0.082 \\
adh-1 & 0.118 & 0.062 & $0.06^{*}$ & 0.098 & 0.066 & $0.038^{*}$ \\
skdh-1 & 0.122 & $0.023^{*}$ & $0.101^{*}$ & 0.165 & 0.034 & $0.135^{*}$ \\
Total & 0.003 & 0.105 & -0.114 & -0.010 & 0.098 & -0.121 \\
\hline
\end{tabular}

IC: $F(-0.124$ to 0.228$), \theta(0.033$ to 0.264$), f(-0.180$ to -0.026$)$. 
expected in tropical trees, and this is because the time between initial environmental disturbance and the real time is short when compared to the longevity, and to the generation period of tropical trees species.

It was evident the formation of two clusters in the results of cluster analysis (UPGMA), by means of genetic diversity $\left(G_{S T}\right)$ matrix between populations. The first cluster was made up of population from PE of Rio Preto and the second was formed by the other populations (Figure 1). If the population of PE of Rio Preto is excluded from the analysis, the measures of diversity of the 15 remaining populations are the following: $H=0.226, G_{\mathrm{ST}}=0.026$ and $F=-0.122$. The parameters $H(0.226)$ and $F$ $(-0.114)$, estimated for the 16 populations, do not change much while $G_{S T}$ is drastically reduced from 0.077 to 0.026 . Thus, approximately $2 / 3$ of the total value of $\mathrm{G}_{\mathrm{ST}}$ in $S$. adstringens are caused by the variation among population of PE of Rio Preto and the other populations. Although a random mating had been found in the population of PE of Rio Preto, the reduced number of migrants per generation (gene flow) shows genetic isolation, so this population is found to be more differentiated than the others, which was confirmed by the results achieved by the cluster method UPGMA.

\section{CONCLUSIONS}

The estimates of genetic diversity of $S$. adstringens are consistent with the ones observed in tropical trees with same distribution characteristics. However, when the population of Rio Preto is excluded, the $G_{S T}$ value is lower than the one found for pine trees from the temperate zones which present large continuous populations and typically low values of $\mathrm{G}_{\mathrm{ST}}$. Thus, it can be concluded that genetic diversity of $S$. adstringens is relatively high within populations and relatively low among populations, with gene flow high enough to prevent diferentiation at the local level, at least.

Preservation of public areas as boarders of highways is very important because they are the only source of germplasm of species native to Cerrado in many regions. Inspection and governmental intervention is needed so those areas will not be deforested and used for farming, as it is extensively found in the state of Goiás.

\section{ACKNOWLEDGMENTS}

To ConselhoNacional de Desenvolvimento Científico e Tecnológico - CNPq (Brazilian Council of Science and Technology) and tot he Fundação de Amparo a Pesquisa- FAPEMIG (Research Support Foundation of the State of Minas Gerais), for the financial support and for granting Doctorate's and Scientific Research's fellowships. To Instituto de Ciências Agrárias -ICA (Agriculture Science Institute) of Universidade Federal de Minas Gerais -UFMG (Federal University of Minas Gerais State) for the logistical support. To Instituto Estadual de Florestas - IEF (Forest State Institute).

\section{REFERENCE}

ALFENAS, A.C.; DUSI, A.; ZERBINI JÚNIOR, F.M.; ROBINSON, I.P.; MICALES, J.A.; de OLIVEIRA, J.R.; DIAS, L.A.S.; SCORTICHINI, M.; PEREIRA, M.C.B.; BONDE, R.B.; de ALONSO, S.K.; JUNGHANS, T.G.; BRUNE, W. (in memoriam). Eletroforese e marcadores bioquímicos em plantas e microorganismos. 2.ed. Viçosa: Editora UFV, 2006. p.85-148.

ALMEIDA, S.P.; PROENÇA, C.E.B.; SANO, S.M.; RIBEIRO, J.F. Cerrado: espécies vegetais úteis. Planaltina: EMBRAPA-CPAC, 1998. 464p.

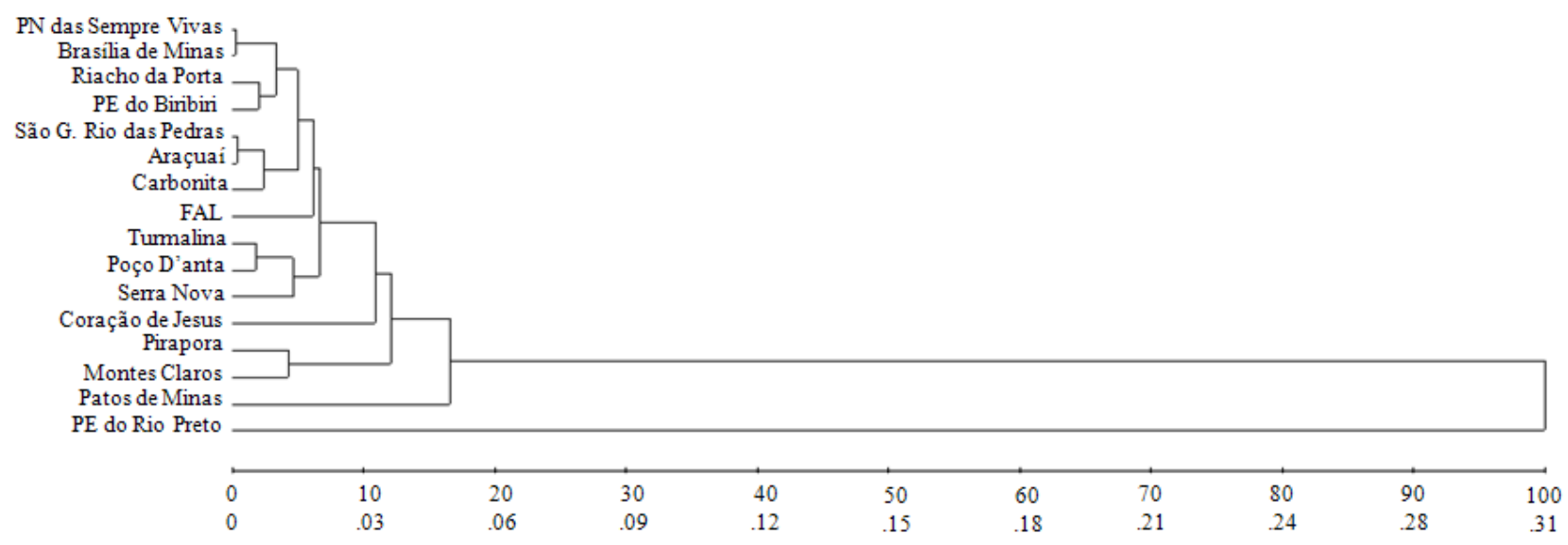

FIGURE 1. UPGMA dendogram obtained by means of genetic diversity matrix $\left(G_{S T}\right)$ calculated from pairs of populations of $S$. adstringens. The first line on the abscissa axis corresponds to the percentage values in relation to dissimilarity of the last fusion level (0.31). PE=Parque Estadual, PN=Parque Nacional, FAL=Fazenda Água Limpa - Universidade Federal de Brasília (UnB), G.= Gonçalo. 
ALVAREZ-BUYLLA, E.R.; GARCIA-BARRIOS, R.; LARAMORENO, C.; MARTÍNEZ-RAMOS, M. Demographic and genetic models in conservation biology: applications and perspectives for tropical rain Forest tree species. Annual Review of Ecology and Systematics, v.27, p.387-21, 1996.

ASSUNÇÃO, S.L.; FELFILI, J.M. Fitossociologia de um fragmento de cerrado sensu stricto na APA do Paranoá, DF, Brasil. Acta Botânica Brasílica, v.18, n.4, p.90309, 2004.

BARROS, M.A.G. Flora medicinal do Distrito Federal. Brasil Florestal, v.12, n.50, p.35-45, 1982.

BAWA, K.S.; ASHTON, P.S. Conservation of rare trees in tropical rain forests: a genetic perspective. In: FALK, D.; HOLSINGER, K. (Eds.). Biology of Rare Plants: Implications for Conservation and Management. London: Oxford University Press, 1991. p. 62-71.

BERG, E.E.; HAMRICK, J.L. Quantification of genetic diversity at allozyme loci. Canadian Journal of Forest Research, v.27, p.415-24, 1997.

BRANCO, E.A.; ZIMBACK, L.; LIMA, A.B.; MORI, E.S.; AOKI, H. Estrutura genética de populações de Stryphnodendron adstringens (MART.). In: SEMINÁRIO DE INICIAÇÃO CIENTÍFICA DO INSTITUTO FLORESTAL, 4., 2010. Disponíevl em: <http://www. iflorestal.sp.gov.br/pibic/4seminario/resumos_pdf/ BRANCO,\%20E.\%20A.pdf>. Acesso em: 18 fev. 2011.

CRUZ, C.D. Programa genes: aplicativo computacional em genética e estatística. Viçosa: Editora UFV, 2008. $278 p$.

CROW, J.F.; AOKI, K. Group selection for polygenic behavioral trait: estimating the degree of population subdivision. Proceedings of the National Academy of Sciences, U.S.A., v.81, p.6073-77, 1984.

ENDLER, J.A. Natural Selection in the wild. Monographs in Population Biology 21. Princeton, NJ: Princeton University Press. 1986. 336p.

FELFILI, J.M.; BORGES FILHO, H.C. Extrativismo racional da casca do barbatimão (Stryphnodendron adstringens [MART.] COVILLE). Brasília, DF: Universidade de Brasília, 2004. 31p.

FEYISSA, T.; NYBOM, H.; BARTISH, I.V.; WELANDER, $M$. Analysis of genetic diversity in the endangered tropical tree species Hagenia abyssinica using ISSR markers. Genetic Resources and Crop Evolution, v.54, p.947-58, 2007.

GAIOTTO, F.A.; GRATAPAGLIA, D.; VENCOVSKY, R. Genetic structure, mating system, and long-distance gene flow in heart of palm (Euterpe edulis Mart.). Journal of Heredity, v.94, n.5, p.399-06, 2003.

GEMMELL, N.J.; SLATE, J. Heterozygote advantage for fecundity. PloS ONE, 1(1):e125. 2006. Disponíevl em: <http://www.ncbi.nlm.nih.gov/pubmed/17205129>. Acesso em: 18 abr. 2011.

GOUDET, J. Fstat version 2.9.3.2. Institute of Ecology. Lausanne, Switzerland, 2002.

HAMRICK, J.L. The distribution of genetic variation within and amount natural plant populations. In: SCHONEWALD-COX, C.M., CHAMBERS, S.M.; MACBRYDE, B.; THOMAS, L. (Eds.). Genetic and Conservation. Califórnia: The Benjamin/Cummings Publishing Company, Inc., Menlo Park, 1983. p.335-48. HAMRICK, J.L.; GODT, M.J.W.; SHERMAN-BROYLES,
S. Factors influencing levels of genetic diversity in wood plant species. New Forest, v.6, p.95-24, 1992.

HAMRICK, J.L.; GODT, M.J.W. Allozyme diversity in plant species. In: BROWN, A.H.D.; CLEGG, M.T.; KAHLER, A.L.; WEIR, B.S. (Eds.). Plant Population Genetics, Breeding and Germplasm Resources. Sunderland: Sinauer Associates, Inc., Publishers, 1989. p.43-63.

HIRSCHMANN, G.S.; ARIAS, A.R. A survey of mrdicinal plantes of Minas Gerais, Brazil. Journal of Ethnopharmacology, v.29, p.159-72, 1990.

IBGE - Instituto Brasileiro de Geografia e Estatística. Diagnóstico ambiental da bacia do Rio Jequitinhonha: diretrizes gerais para a ordenação territorial. Salvador: 1997. Disponível em: <www.ibge. gov.br>. Acesso em: 25 maio 2011.

IBGE - Instituto Brasileiro de Geografia e Estatística. Divisão Territorial do Brasil e Limites Territoriais. 2008. Disponível em: <www.ibge.gov.br>. Acesso em: 25 maio 2011.

JACOBSON, T.K.B.; GARCIA, J.; da COSTA SANTOS, S.; DUARTE, J.B.; FARIAS, J.G.; KLIEMANN, H.J. Influência de fatores edáficos na produção de fenóis totais e taninos de duas espécies de barbatimão (Stryphnodendron sp.). Pesquisa Agropecuária Tropical, v.35, n.3, p.163-69, 2005.

LI, C.C.; HORVITZ, D.G. Some methods of estimating the inbreeding coefficient. American Journal of Human Genetics, v.5, p.107-17, 1953.

LOVELESS, M.D.; HAMRICK, J.L. Ecological determinants of genetic structure in plant population. Annual review of ecology and systematic, v.15, p.65-95, 1984.

LOVELESS, M.D. Isozyme variation in tropical trees: patterns of genetic organization. New Forests, v.6, p.67-94, 1992.

MELLO, A.O. Patos de Minas, meu bem querer. 3. ed. Patos de Minas: Edição Prefeitura Municipal/SEMED, 2008. 127p

NEI, M.; KUMAR, S. Molecular evolution and phylogenetics. New York: Oxford University Press, 2000. p.231-64.

SHAW, C.R.; PRASAD, R. Starch gel electrophoresis of enzymes: a compilation of recipes. Biochemical Genetics, v.4, p.297-20, 1970.

SOLTIS, D.E.; HAUFLER, C.H.; DARROW, D.C.; GASTONY, G.J. Starch gel electrophoresis of fern: a compilation of grind buffers, gel and electrode buffers, and staining schedules. American Fern Journal, v.73, n.1, p.9-27, 1983.

SOUZA, C.D.; FELFILI, J.M. Uso de plantas medicinais na região de Alto Paraíso de Goiás, GO, Brasil. Acta Botânica Brasilica, v.20, n.1, p.135-42, 2006.

STOECKEL, S.; GRANGE, J.; FERNÁNDEZMANJARRES, J.F.; BILGER, I.; FRASCARIALACOSTE, N.; MARIETTE, S. Heterozygote excess in a self-incompatible and partially clonal forest tree species Prunus avium L. Molecular Ecology, v.15, p.2109-118, 2006.

TELLES, M.P.C.; VALVA, F.; BANDEIRA, L.F.; COELHO, A.S.G. Caracterização genética de populações naturais de aratincunzeiro (Anonna crassiflora Mart. Annonaceae) no Estado de Goiás. Revista Brasileira de Botânica, v.26, p.123-29, 2003a.

TELLES, M.P.C.; COELHO, A.S.G.; CHAVES, L.J.; 
DINIZ-FILHO, J.A.F.; VALVA, F. Genetic diversity and population structure of Eugenia dysenterica DC. ("cagaita" - Myrtaceae) in Central Brazil: Spatial analysis and implications for conservation and management. Conservation Genetics, v.4, 685-95, 2003b.

VENCOVSKY, R. Biometrical approaches for molecular markers estimation of effective population size. In: THE INTERNATIONAL WORKSHOP ON AGRICULTURAL BIOTECHNOLOGY, 1997, Piracicaba. Proceedings of the international workshop on agricultural biotechnology: Esalq/USP, 1997. p.233-34.

WEIR, B.S.; COCKERHAM, C.C. Estimating F-statistics for the analysis of population structure. Evolution, v.38, p.1358-70, 1984.

WHITMORE, T.C. The conservation of tropical rain forest. In: SOULÉ, M.E.; WILCOX. B.A. (Eds.). Conservation Biology: An Evolutionary-Ecological Perspective. Sunderland: Sinauer Associates, Inc., Publishers, 1980. p. 303-18. 